\title{
Acrostic techniques as an effort to increase motivation and the ability to write poetry students
}

\author{
Lenny Apriliany ${ }^{1}$, Dessy Wardiah ${ }^{2}$, Yessi Fitriani ${ }^{2}$ \\ ${ }^{1}$ Sekolah Menengah Pertama Negeri 14 OKU, Indonesia \\ ${ }^{2}$ Universitas PGRI Palembang, Indonesia
}

\section{Article Info}

\section{Article history:}

Received Jul 26 ${ }^{\text {th }}, 2021$

Revised Aug $18^{\text {th }}, 2021$

Accepted Aug 30, 2021

\section{Keyword:}

Writing in poetry

PTK

Acrostic technique

\begin{abstract}
This classroom action research entitled Acrostic Technique as an Effort to Increase the Motivation and Ability to Write Poetry for VIII Grade Students of SMP Negeri 14 OKU. This study involved 24 eighth grade students who have different backgrounds and abilities in writing poetry. By using acrostic techniques, this classroom action research is planned to use two research cycles with a KKM value of 75 and a success rate of above $75 \%$. Based on the results of the data analysis of classroom action research in the first cycle, it was found that the teacher's observation score was very good with a value of 3.33 , the value of student observation also reached $62.5 \%$ success, and the student's poetry writing score reached $66.6 \%$. In the second cycle, there was a very significant increase. The teacher's observation value increased to 3.55 , the student's observation score also increased, making the success rate $100 \%$ and the value of writing poetry, all students succeeded in exceeding the KKM score of 75 so that the success percentage was $100 \%$. Thus the classroom action research was declared successful and was stopped in the second cycle. From these results, it can be concluded that acrostic techniques can improve students' ability to write poetry.
\end{abstract}

C) 2021 The Authors. Published by IICET.

This is an open access article under the CC BY-NC-SA license (https://creativecommons.org/licenses/by-nc-sa/4.0

\section{Corresponding Author:}

Apriliany, L.,

Sekolah Menengah Pertama Negeri 14 OKU, Indonesia

Email: lennycutelenny@yahoo.co.id

\section{Introduction}

Basically speaking is a process that emphasizes the interactive communicative aspects of language. The ability to understand these aspects will determine the success in the communication process. These aspects of language include the ability to listen, speak, read and write. The four abilities stand alone, but the use of language as a communication process cannot be separated from one another. This shows that language is an integration of several aspects. Likewise, these language skills are found in literature, one of which is writing. The ability to write literature in Indonesian subjects has a specific goal, as well as language skills. Literary works can arise from the results of the author's reflection on existing phenomena or problems through good understanding. Besides creativity, the author is required to be able to relate the best elements of human life experiences [1]. In the SMP syllabus, there are Basic Competencies 4.8 Presenting ideas, feelings, opinions, in the form of written / oral poetry texts with the main material of expressing ideas, feelings, views of the writer and learning about writing poetry based on context.

Writing activities are an integral part of the entire learning process experienced by students [2]. Likewise with writing poetry. The material for writing poetry in class VIII SMP students is in accordance with the 
context related to the students' own writing ability. With limited knowledge, diction vocabulary, and other writing techniques, a really precise technique is needed in learning to write poetry. Writing skills are complex and concrete skills. For that, writing skills are more difficult than other language skills. Compared to the other three language skills, writing skills are more difficult to master even by expert speakers [3]

Writing poetry is one of the aspects that must be studied in learning material in class VIII SMP. Researchers are teaching staff as Indonesian language teachers at SMP Negeri 14 OKU. Teaching experience must complete the material within a predetermined time, while teaching materials must be completed within a timeframe that has been adjusted to the academic calendar of SMP Negeri 14 OKU. So, researchers always dominate the lecture method (conventional) and assignment in learning. Based on the results of preliminary observations, it can be seen that most of the eighth-grade students of SMP Negeri 14 OKU still score below the specified minimum completeness criteria (KKM), namely 75 . The object of this research is class VIII-D, totaling 24 students because they are deemed to need it. action in an effort to improve the ability to write poetry. This is seenFrom the results of learning to write poetry, there were 20 students $(80 \%)$ who scored below the KKM, 5 students $(20 \%)$ who scored above the KKM. In addition, based on the results of interviews with several students in the class that they find it difficult to express their ideas in the form of poetry because poetry requires language that contains figurative meaning. Furthermore, so far, researchers in carrying out learning have dominated the lecture method with a conventional approach so that students pay less attention when the teacher explains the learning material. This method is sometimes boring because communication only occurs in one direction (the teacher who speaks, the students only see and listen). Students are not directly involved in the learning process so they are passive. In delivering poetry writing material, the teacher only explains the physical and inner structure of the poetry and then assigns students to write poetry.

In addition, when participating in learning in the classroom, students are less motivated, especially when participating in learning to write poetry. Even when conducting initial interviews with student representatives, they thought that writing poetry material was the most difficult thing to follow, so writing poetry was one of the most boring materials. For this reason, the researcher wants to do research to improve the motivation and writing skills of the eighth-grade students of SMP Negeri 14 OKU by using acrostic techniques. Acrostic technique is one of the techniques of writing poetry using the initial letters of the names of people, objects, cities, and so on. This acrostic technique is a poetry writing technique for beginners so that it is expected to increase the motivation and ability to write poetry for eighth-grade students of SMP Negeri 14 OKU.

Based on the description above, the researcher will conduct research in an effort to improve the ability to write poetry and student motivation by using acrostic techniques. This study entitled "Acrostic Techniques as an Effort to Increase the Motivation and Ability of Grade VIII Students of SMP Negeri 14 OKU". The purpose of this study was to increase the learning motivation of grade VIII students of SMP Negeri 14 OKU through acrostic techniques and to improve the ability to write poetry of grade VIII students. SMP Negeri 14 OKU through acrostic techniques. Traditional acrostic make use of a key name or phrase written vertically, where each line of the poem begins with a letter of the keyword. Traditional acrostics use a name or phrase written vertically, ie each line in poetry starts with the first letter of the keywords used [4]. Acrostics use key names or phrases written vertically and each line of poetry starts with the first letter of the keyname. or the expression [5]. In learning, there are motivations that must be built-in students.

Motivation is an impulse that arises by stimulation from within or from outsideso that someone wants to make changes in behavior / certain activities better than the previous situation. Motivation is a series of activities carried out by each party that is actually motivated by something or something in general [6]. Motivation is what encourages them to do a job or activity. With the following objectives: (a) encouraging people to carry out an activity based on meeting needs. In this case, motivation is the driving force of every need to be fulfilled, (b) determines the direction of the goals to be achieved, and (c) determines the actions that must be done.Motivation is a change in energy in a person characterized by the emergence of "feelings" and preceded by a response to the purpose. The meaning expressed by Mc. Donald contains three important elements. First, motivation arises from the energy that appears in a person individually. Motivation develops by bringing about some of the energy changes in the "neurophysiological" system that exists in the human organism [7].

Motivation encourages people to do an activity / job. Likewise for learning, motivation is needed. Motivation is an essential condition of learning. For those who get good results, of course, these results can motivate the maintenance and increase the results. Besides encouraging students to learn better [8]. Learning outcomes will be optimal, if there is motivation. The more precise the motivation is given, the more successful the lesson will be. So motivation will always determine the intensity of learning efforts for students. Talking about the kinds or types of motivation can be seen from various points of view. Thus, motivations or active motives vary widely. As a form of verbal communication (language), writing can also be defined as an activity 
to convey messages using writing as the medium. The message is the content or content contained in an article [9]. Writing is a communication system between people that uses symbols or language symbols that can be seen and agreed upon by the user. Writing means dealing with the possibility of getting stuck, the risk of being rejected as well as being criticized. Writing requires time, concentration, editing practice, and special attention $[10]$.

Writing is an activity that conveys or expresses the results of thoughts, ideas, ideas in writing. In this process, writing consists of the stages of activities that must be passed to produce writing [11]. Writing is a form of communication. Writing means a separate form of communication that is indicated forthe reader's ignorance. Writing is also a symbolic activity that produces meaning, like an actor on a stage to convey meaning to others, and a way to express oneself and a means of communicating with others. 'writing is having ideas, organizing ideas, and communicating ideas "(writing is finding ideas, organizing ideas, and communicating ideas) [12]. Writing is a language skill that language learners have most recently mastered after listening, speaking, and reading skills. Compared to the other three language skills, writing is often considered the most difficult skill to master [13].

Poetry is a genre or type of literature. Often the term "poetry" is equated with "poetry". Etymologically, the term poetry comes from the Greek poem "to make" or poesis "manufacture" and in English, it is called poem or poetry. However, this original meaning has gradually narrowed its scope to become the result of literary art, whose words are arranged according to certain conditions by using rhythms, rhymes, and sometimes figurative words. the experience that is interpretive (interpreting) in rhythmic/meaningful language [15]. Poetry is a form of literary work that uses beautiful words contained in literary work. [16] Poetry is a literary work with condensed language, shortened and given a rhythm with a unified sound and choice of study words (imaginative) [17 ]. Poetry is a branch of literature that uses words as a medium of delivery to produce illusions and imagination [18].

Poetry is a form of pronouncing ideas that are emotional by considering the effect of beauty [19]. Poetry structure is the elements that make up a poem, both language (physical structure) and content that the poet intends to convey with his feelings and mental atmosphere (inner structure). [20] Poetry structure is a systemic arrangement of elements, which between elements -the elements occur reciprocal relationship and determine each other [21]. Poetry structure is concentration and intensification in which there are elements of emotion and imagination [22]. Poetry is a literary work that uses beautiful words, accompanied by a supportive melody and composition. beautiful sentences. Poetry has an implied meaning. Poetry can be used to describe feelings and even expressions of your own heart. Poetry can represent the feelings of the poet. The existence of poetry can be a means of conveying other messages [23].

\section{Method}

This research includes Classroom Action Research (PTK). This research was conducted on class studentsVIII SMP Negeri 14 OKU academic year 2020/2021 as the object of research. The selection of SMP Negeri 14 $\mathrm{OKU}$ as the object of research is based on the fact that the researcher is the Indonesian language teacher at the school so that it is easier to find out the problems faced during the learning process. The total student population is 110 students consisting of four classes. In this study, the researcher will only choose one class, namely 24 students of class VIII-D as the research object. The reason for determining class VIII-D students as research objects is in accordance with the results of initial observations during the previous learning process. Class VIII-D has the characteristics of class VIII-C, but the ability of class VIII-D students has an average score lower than class VIII-C. Likewise, classes, VIII-A, and VIII-B have an average score above class VIII-C. Thus, the researcher took class VIII-D to be the object of this research with the assumption that the average ability of the students was still ideal enough to be improved. After the implementation of the action in the first cycle of learning ended, the teacher reflected on the learning results. If most of the student's ability results are still low (below the KKM score), then the teacher is obliged to carry out the next cycle of learning actions. For students who have received a minimum score of 65 , they have been declared successful (complete), while students whose grades are still below 65 are declared not yet successful (not finished).

\section{Results and Discussions}

Based on the results of teacher observation data processing, the scores obtained fall into the very good category. The average value of teacher observations in this first cycle was 3.3. There are six assessment criteria that have not received maximum results by the researcher, namely; in the method application section, especially for the item according to the syntax sequence with the method used, in the section on the use of 
teaching media there are two items that have not been maximized, namely, the accuracy of media selection With the material and skills of using the media, in the performance section, items that are not yet optimal are the communication of teachers and students, as well as in the part of providing motivation, teacher enthusiasm is still considered less than optimal by peers and also accuracy in giving praise (reward) and punishment (punishman) These six assessment items will be the focus of improvement by the researcher in the next cycle. After observing the teacher, the next step is to observe the students. This observation of students aims to determine the level of student interest in the learning method, the activeness of students in following the learning process, their active role in the learning process, the seriousness of participating in learning andalso their responsibility towards the assignment given by the teacher. This observation was also carried out to determine the extent of students' motivation to take part in learning, especially learning to write poetry using this acrostic technique.

Based on the results of student observations made by the teacher, the value of student motivation is good enough. Of the 24 students, 4 students whose observation scores were in the poor category, 4 other students on average were in the enough category, and 16 were good. The lowest score of the student was 67.85 while the highest score was 89.28. As a percentage, the students who had succeeded in this first cycle were $62.5 \%$, which means that more than half of the class had managed to get good grades and succeeded in this first cycle.

Based on the results of the observation data analysis above, it can be seen that students' motivation in learning to write poetry using acrostic techniques is very good. Of the 24 students, it is known that 7 students are in the Enough category, 5 students are in a Good category, and 12 other students are already in the Very Good category. As a percentage, the success rate of student motivation in this first cycle reached $70.83 \%$. The next step is to analyze the students' poetry writing data using acrostic techniques. From the data on writing this poem, it can be seen if the expected results are not yet optimal. There were at least four students whose writing scores were still in the Less category with the lowest score of 60, four students were in the Enough category, and sixteen students scored in the Very Good category with the highest score of 95.

After analyzing the teacher's and student's observation data, the next step was to analyze the students' poetry writing data using acrostic techniques. From the data on writing this poem, it can be seen if the expected results are not yet optimal. There were at least four students whose writing scores were still in the Less category with the lowest score of 60, four students were in the Enough category, and sixteen students scored in the Very Good category with the highest score of 95 . Based on the results of the analysis above it can be seen if the level the success in this first cycle has been very good. Of the 24 students, 16 people have received excellent and satisfying scores, meaning that the success rate in this first cycle has reached $66.66 \%$. Although there are still four people who score 60 and 4 people with a score of 70 , which means that they have not reached the specified KKM score of 75. However, the success rate in this first cycle is quite good. From the analysis results, it is also known that of the five existing assessment categories, The mistake most often made by students is the use of deep concrete wordswriting poetry, the accuracy of diction that is used is still not quite right, and enrichment of language style. Especially for the empowerment of visualization, students are still not able to make poetry using existing figures of speech. There are still many poems that only play with rhymes or just simple parables.

Meanwhile, the novelty of the theme is good enough, students can use their names as material for making poetry using this acrostic technique. For imaging is also quite good, students are able to provide good images and colors in the poetry they make, even though it is still not too optimal. The three categories that are still weaknesses of students in this first cycle will be of special concern for researchers to be able to find a more better from acrostic techniques so that the problem does not recur in the next cycle so that this research can be successful in accordance with the expectations of the researcher.

Based on the results of processing teacher observation data, student observation data, and the results of writing poetry using student acrostic techniques in this first cycle, there are several things that must be improved and emphasized so that further action can provide maximum results. very good with a value of 3.3. Of the 18 assessment items, there are at least 6 assessment criteria that must be maximized in the second cycle, namely; in the implementation of the method, especially for the item corresponding to the syntax sequence with the method used, in the section on the use of teaching media there are two items that have not been maximized, namely, the accuracy of selection. media with materials and skills in using media, in the performance section, items that are not yet optimal are the communication of teachers and students, and in the part of providing motivation, teacher enthusiasm is still considered less than optimal by peers and also accuracy in giving praise (reward) and punishment (punishment).

Based on the results of the analysis on the student's observation data, it was quite good, only 9 students whose motivation values needed to be increased in the next cycle. The percentage of success in this first cycle 
was also quite good, namely $62.5 \%$, which means that more than half of the class had managed to get a score good and successful in this first cycle. The activities of peers who fill in teacher observation data and documentation will also be made more natural because in cycle It can be seen that the presence of other teachers in the classroom makes them a little uncomfortable and a little disturbed by the photoshoot which is conducted. The success rate in this first cycle has reached $66.66 \%$. There are still four students who need more attention in the second syllabus later, the value of 60 they get is one indicator that is vital enough to be considered. And also 4 people with a score of 70 still need to be improved again in order to achieve the KKM value that has been determined at 75 .

The results of data processing on teacher observation sheets in cycle II show a very significant increase. Based on the results of data processing that has been done, it is known that the teacher's observation score that was successfully achieved in cycle II was 3.55. of course this is something to be very proud of. This can also prove that the competence of the teacher / researcher is very good and capable. It can be seen if there is only one assessment item left that still has not got the maximum value, namely in the part of giving motivation, the item of the accuracy of giving praise and punishment (reward and punishment). This proves that the teacher / researcher has excellent competence in implementing and implementing learning techniques and also have capable management in controlling the class. For student observation sheets, the improvements that occurred were also very significant. Until the end of this second silkus action, there were only five students whose observation scores were in the good category, while the other 19 were very good. Based on these data, it can be stated if the level of appreciation and motivation of students in following the learning process with this acrostic technique has increased significantly compared to the first cycle.

Of the seven observation items in this student observation instrument, it can be seen that the level of student discipline is the highest, this is evidenced by the high value of the student assessment items following the learning until the end. All students follow the learning process until the end, besides that the highest item is also in the assessment of the attention given by students to the explanation of the material given by the teacher/researcher. Meanwhile, the assessment that is still normal but good enough is the item about students' courage in expressing opinions and also asking questions related to learning materials to write poetry using this acrostic technique. The next step is to carry out re-sequencing related to the student's motivation level in following the learning process to write poetry using acrostic techniques. In the second cycle, the value of student learning motivation increased significantly. If in cycle 1 there are still 7 people in the Enough category, then in this second cycle there are no longer in the Enough category. In this second cycle, only 5 students were left in the Good category, and 19 other students were in the Very Good category with the highest score reaching 92 . If in perspective, the success rate of student motivation in this second cycle reached $100 \%$. Thus, it can be concluded if motivationStudent learning is already very high. Meanwhile, the results of writing poetry using acrostic techniques in the second cycle also show a very significant increase compared to the action in the first cycle. Until the end of this second cycle of action, there was not a single student whose score did not reach the KKM score that had been previously set at 75 . Only five students scored 75 , the rest got a score in the range of 80-90 more. This increase in writing skills certainly brings a change in the percentage of research success. Until the end of this cycle II, the percentage of successful research that has been achieved is $100 \%$, meaning that the research target has been successfully exceeded. This increase shows that the ability to write students' poetry has increased significantly. For more details, the increase in the value of the ability to write descriptions in cycle II. If in the first cycle the success rate of students was only $66.66 \%$, leaving four students who had not got the maximum score, four people who were good enough but had not reached the set KKM score, and only 16 people were declared complete, in this second cycle, the twenty-four students squads succeeded in achieving the KKM score determined with a success rate of $100 \%$. This shows that the acrostic technique applied in learning poetry in class VIII SMP Negeri 14 Ogan Komering Ulu ( OKU) worked out really well. Students are highly motivated in participating in learning to write poetry using acrostic techniques. Based on the results of the analysis of teacher observation data, it can be seen if the teacher has excellent competence in teaching. The teacher can also motivate the teacher to take part in learning to write poetry using acrostic techniques. The results of writing poetry in this second cycle also experienced a very significant increase. If in the first cycle the success percentage is still $66.66 \%$, then in this second cycle, the success rate reaches $100 \%$ with a very good number, namely $75-96$. Of course, this proves if the success rate of acrostic techniques in writing poetry material can be applied properly.

The value of 3.3 is already in the very good category, but the six items of assessment that have not been maximal out of 18 items become a note for researchers to further improve their performance in the next cycle. As for the results of student observation scores, the scores achieved are also quite good. The scores obtained by the students were quite good, of the 24 students there were only four students whose observation scores were still inadequate, 4 were at the sufficient level, and 16 people had reached the very good category level. The percentage increase in student observation results reached $62.5 \%$. For the results of writing student 
descriptions, researchers still need improvements so that the results obtained in the next cycle can be even better. The results of this cycle I action are still quite far from the target to be achieved. The highest score for writing poetry by students had reached 95 and the lowest was 60 . Of the 24 students, only 16 students scored reached the KKM score set by the school. , namely, 75, while the other 8 people still need to be improved. The percentage of research success at the end of the first cycle is still quite low, namely $66.66 \%$. This percentage is still quite far from the research target that the researcher wants to achieve, which is $75 \%$. Based on the results of the data processing, it can be concluded that the students' poetry writing scores still need better attention from researchers and some improvements need to be made in the next cycle.

Based on the results of data processing on three aspects of assessment instruments, namely teacher observation sheets, student observation sheets, and a poetry writing test using acrostic techniques at the end of the action cycle I. It is known that the lowest aspect of assessment lies in the students' writing ability. The results were very satisfying, although there are several aspects of assessment that have not been maximized by researchers. There are at least six assessment criteria that have not got maximum results by the researcher, namely; in the method application method, especially for the suitability item of the syntax sequence with the method used, in the section on the use of teaching media, there are two items that have not been maximized, namely, the accuracy of selecting media with material and skills. Using the media, in the performance section, items that are not optimal are a teacher and student communication, as well as in the part of providing motivation, teacher enthusiasm is still considered less than optimal by peers and also accuracy in giving praise (reward) and punishment (punishment). The value of 3.3 is already in the very good category, but the six assessment items that have not been maximal out of 18 items become a note for researchers to further improve their performance in the next cycle.

The scores obtained by the students were quite good, of the 24 students only four students whose observation scores were still inadequate, 4 were at the sufficient level, and 16 people had reached the very good category level. The percentage increase in student observation results reached $62.5 \%$. For the results of writing student descriptions, researchers still need improvements so that the results obtained in the next cycle can be even better. The results of this cycle I action are still quite far from the target to be achieved. The highest score for writing poetry by students had reached 95 and the lowest was 60 . Of the 24 students, only 16 students scored reached the KKM score set by the school. , namely, 75, while the other 8 people still need to be improved. The percentage of research success at the end of the cycle also stillquite low, namely $66.66 \%$. This percentage is still quite far from the research target that the researcher wants to achieve, which is $75 \%$. Based on the results of the data processing, it can be concluded that the students' poetry writing scores still need better attention from researchers and some improvements need to be made in the next cycle.

Based on the results of teacher observation data processing in cycle II, it is known that if the teacher's observation value again increases very well, the value obtained is 3.55. From the two cycles that have been carried out, it is proven that the teacher factor is not the cause of the students' low writing ability. The teacher has excellent competence in carrying out the learning process and managing the class. For student observation sheets, the improvement that occurs is very significant. Until the end of this second cycle, five students were in the good category, while 19 others were in the very good category. The grades achieved by students are also very satisfying. The highest value is 96.42 , and the lowest value is 75 .

The increase also occurred in the results of the students' ability to write descriptions. In this second cycle, the scores obtained by students are very good, this may be influenced by the choice of themes that tend to be easier for students, namely using objects that are around them. So that it makes students have a lot of information and an overview of what they will write.

\section{Conclusions}

Based on the results of data processing that has been carried out, it can be concluded that acrostic techniques can improve the ability to write poetry for students, especially students in class VIII.D SMP Negeri 14 OKU. This can be seen from the increase that occurred in the results of writing poetry from cycle I to the end of the action in cycle II. The improvements achieved per action cycle indicate that the acrostic technique is one of the learning strategies that can be used as an alternative to learning to write, especially writing poetry for junior high school students. Acrostic techniques can have a positive effect on student learning motivation. After using acrostic techniques, students are more active and appreciative in following the learning process. Acrostic techniques can be used as a creative and innovative alternative learning strategy in an effort to improve students' writing skills, especially writing poetry for junior high school students. 


\section{References}

Wardiah, D. (2017). Nilai-Nilai Pendidikan pada Novel Pak Guru Karya Awang. Jurnal Dosen Universitas PGRI Palembang, 210.

Astuti, S., \& Fitriani, Y. (2019). Pengaruh Model Pembelajaran Circuit Learning Terhadap Keterampilan Menulis Naskah Drama Kelas XII IPS SMA Negeri 3 Unggulan Palembang. PEMBAHSI, 9 (2), 2. Retrieved from

Nurgiyantoro, B. (2012). Penilaian Pembelajaran Bahasa Berbasis Kompetensi. Yogyakarta: BPFE.

Frye, E. (2010). Extending Acrostic Poetry Into Content Learning: A Scaffolding Framework. The Reading Teacher. Academia Edu, 591.

Abduh, N. K. (2018). Pemanfaatan Teknik Akrostik untuk Meningkatkan Kemampuan Menulis Puisi. Bahasa, Sastra dan Pengajarannya, 42. Retrieved from https://ojs.unm.ac.id/retorika/article/view/4979

Nurgiyantoro, B. (2012). Penilaian Pembelajaran Bahasa Berbasis Kompetensi. Yogyakarta: BPFE.

Sardiman. (2011). Interaksi dan Motivasi Belajar Mengajar. Jakarta: PT Raja Grafindo.

Widoyoko, E. P. (2010). Evaluasi Program Pembelajaran. Yogyakarta: Pustaka Pelajar.

Sardiman. (2011). Interaksi dan Motivasi Belajar Mengajar. Jakarta: PT Raja Grafindo

Effendi, W. (2012). Taktik Menulis Fiksi. Jakarta Selatan: Gagas Media.

Bachtiar, D. Y., \& dkk. (2014). Peningkatan Keterampilan Menulis Puisi dengan Menggunakan Media Kartu Kata Bergambar pada Siswa Kelas III SDI Al-Khairiyah Banyuwangi. Edukasi UNEJ, 1 (3), 26.

Wardarita, R. (2010). Kemampuan Menulis Karya Ilmiah. Yogyakarta: Pararaton.

Mulyono, S., \& dkk. (2014). Peningkatan Motivasi Dan Keterampilan Menulis Puisi Dengan Penerapan Pendekatan Kontekstual. Penelitian Bahasa, Sastra Indonesia Dan Pengajarannya, 1 (3), 573.

Tarigan, H. G. (2012). Menulis Sebagai Keterampilan Berbahasa. Bandung: Angkasa.

Pradopo, R. J. (2012). Pengkajian Puisi. Jakarta: UMG Press.

Kosasih, E. (2013). Kajian Sastra. Jakarta: Rajawali Press.

Rani, Y. M. (2012). Apresiasi Sastra Indonoesia. Jakarta: Nobel Edumedia.

Wardoyo, M. S. (2013). Teknik Menulis Puisi. Yogyakarta: Graha Ilmu.

Waluyo, J. H. (2005). Teori dan Apresiasi Sastra. Jakarta: Rajawali Pers.

Wardoyo, M. S. (2013). Teknik Menulis Puisi. Yogyakarta: Graha Ilmu.

Pradopo, R. J. (2012). Pengkajian Puisi. Jakarta: UMG Press.

Waluyo, J. H. (2005). Teori dan Apresiasi Sastra. Jakarta: Rajawali Pers.

Tarigan, H. G. (2012). Menulis Sebagai Keterampilan Berbahasa. Bandung: Angkasa. 